\title{
Short Contribution: Nile Flow Failure at the End of the Old Kingdom, Egypt: Strontium Isotopic and Petrologic Evidence
}

\author{
Jean-Daniel Stanley, ${ }^{1, *}$ Michael D. Krom, ${ }^{2}$ Robert A. Cliff, ${ }^{2}$ \\ and Jamie C. Woodward ${ }^{3}$ \\ ${ }^{1}$ Geoarchaeology-Global Change Program, E-206 NMNH, Smithsonian \\ Institution, Washington, DC 20560 \\ ${ }^{2}$ School of Earth Sciences, University of Leeds, Leeds LS2 9JT, United Kingdom \\ ${ }^{3}$ School of Geography, University of Leeds, Leeds LS2 9JT, United Kingdom
}

\begin{abstract}
Strontium isotopic and petrologic information, obtained from sediment cores collected in the Nile delta of Egypt, indicate that paleoclimatic and Nile baseflow conditions changed considerably from about 4200 to 4000 cal yr B.P. in the Nile basin. Our study records a higher proportion of White Nile sediment transported during the annual floods at ca. $6100 \mathrm{cal}$ yr B.P. than towards $4200 \mathrm{cal}$ yr B.P., at which time suspended sediment from the Blue Nile formed a significantly larger fraction of the total load. This resulted from a decrease in vegetative cover and an increase in erosion rate accompanying the marked decline in rainfall. These new geoscience data indicate major changes in annual flooding and baseflow of the river Nile, marked short-term paleoclimatic-related events that may in part have led to the collapse of the Old Kingdom. (C) 2003 Wiley Periodicals, Inc.
\end{abstract}

\section{INTRODUCTION AND BACKGROUND}

Since Predynastic time, Egypt's civilization, positioned in the northeastern Sahara, has been directly linked to the Nile, its one primary and vital water source (Figures 1A, 1B). There are few examples where the interaction of climate, hydrological flux, and human development is so closely intertwined (Butzer, 1976). Here we present new geological data from cores collected in the Nile delta that substantiate the archaeological hypothesis that natural environmental events, and particularly a drying trend and failure of Nile flow, played a major role in the demise of the Old Kingdom in Egypt (Bell, 1971; Hassan, 1997).

Historical and paleoevironmental records have suggested a long-term decline in rainfall in the Sahel region and a gradual drying of the Egyptian hinterland from the Predynastic period (ca. 6000 cal. yr B.P.) to Old Kingdom time (to ca. 4300 cal. yr B.P.) (Bell, 1971; Said, 1993). ${ }^{1}$ A gradual decrease in precipitation is evident in the range and diversity of plants and animals depicted in reliefs of this period. Tree

* Author for correspondence: e-mail: stanley.daniel@nmnh.si.edu.

${ }^{1}$ All dates herein are calibrated, except those that are archaeological dates in calendric yr B.C.

Geoarchaeology: An International Journal, Vol. 18, No. 3, 395-402 (2003)

(C) 2003 Wiley Periodicals, Inc.

Published online in Wiley Interscience (www.interscience.wiley.com). DOI:10.1002/gea.10065 

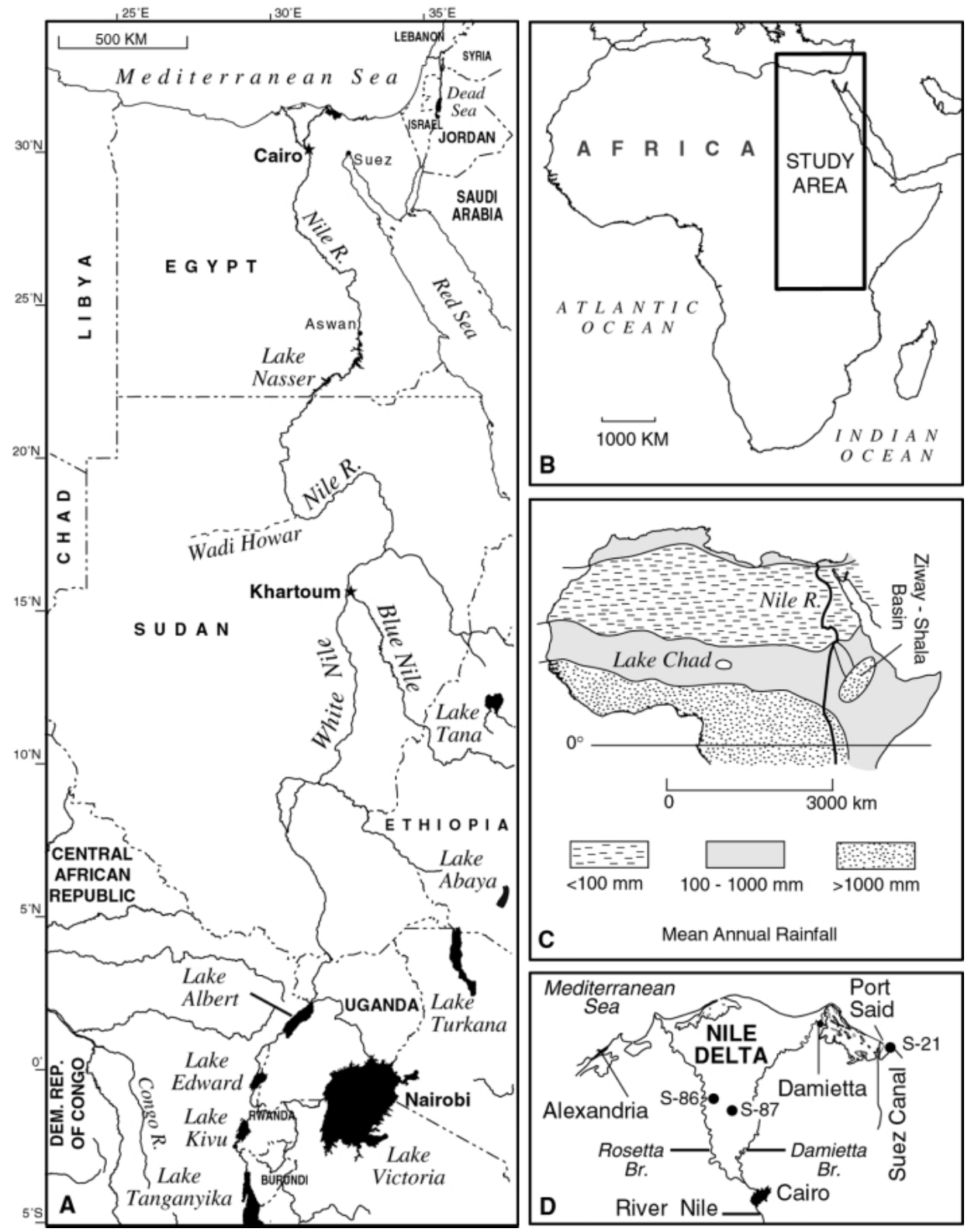

Figure 1. (A) Map of the Nile catchment area showing the principal lakes and tributaries that supply water and sediment to the present main Nile. Note the location of Wadi Howar (or Yellow Nile) which flowed prior to $4500 \mathrm{cal}$ yr B.P. (B) Map of Africa showing the position and extent of the Nile drainage basin. (C) Present mean annual rainfall distribution on the African continent; these belts shifted north and south considerably during the Holocene. (D) Map of the Nile delta showing the locations for the three sediment cores discussed in this study. 
roots of acacias and tamarisks identified in many Predynastic desert sites subsequently disappeared (Said, 1993). During the Old Kingdom (ca. 2575-2134 B.C.), some of the reliefs of Dynasty $\mathrm{V}$ tombs show a low desert landscape, with sycamore and smaller bushes that do not appear in later reliefs.

Data have been collected from several lakes in the Nile catchment which provide direct evidence of this drying trend in the region (Adamson et al., 1980; Ritchie et al., 1985; Street-Perrott and Perrott, 1990; Gasse, 2000). For example, Abhe and Ziway-Shala lakes are located in the East African rift valley and are fed by rivers that rise in the Ethiopian Highlands close to the sources of the Blue Nile and Atbara rivers (Figure 1C). These lakes record decreasing water levels during the midHolocene reaching a minimum at ca. 4200 cal yr B.P. (Gillespie et al., 1983; Gasse and van Campo, 1994). Isotopic evidence from freshwater snails in two smaller lakes from the Ethiopian rift valley indicates fully freshwater conditions from ca. $10,000 \mathrm{cal}$ yr B.P., followed by a period of decreasing rainfall until after $6300 \mathrm{cal}$ yr B.P., when the lake's diatom flora was dominated by saline tolerant species (Leng et al., 1999). The level of Lake Turkana, located on the edge of the White Nile catchment, also decreased to a minimum at ca. 4400 cal yr B.P. (Owens et al., 1982). These widespread hydrological changes have been interpreted as a result of southerly displacement of the climatic belts relative to their present position (Figure 1C; Street-Perrott and Perrott, 1990).

While there is extensive information in support of this major paleoclimatic change from lake basins in the catchment, relatively little data document this drying trend downstream in the river valley itself and the Nile delta (Figure 1D). A general decrease in humidity from ca. 8000 to 4500 cal yr B.P. has been recorded in Wadi Soba, just east of Khartoum in the Blue Nile valley (Lario et al., 1997). This conclusion was based on archaeological, petrological, and ecological evidence. In the Northern Dongola Reach in Northern Sudan, major changes in valley floor settlement patterns have been recorded after ca. 4500 cal yr B.P. when the onset of the Kerma Period saw all settlements located in close proximity to a series of midHolocene channel belts as the local climate became drier (Welsby, 2001; Woodward et al., 2001). In lower Egypt, a decline is evident in the level of lake Quarun in the Faiyum (approximately $100 \mathrm{~km}$ southwest of Cairo) during the late Predynastic and early Dynastic periods (Butzer, 1976; Hassan 1986). This lower Nile basin serves as a valuable gauge since it receives overflow water at the time of abundant annual Nile floods (Hassan, 1997).

\section{${ }^{87}$ SR/86SR RATIO AS A PALEOCLIMATIC INDICATOR IN NILE SEDIMENTS}

During the Holocene, major changes in the rate of erosion in a given Nile subcatchment are controlled to a large extent by climatic conditions. Information on the provenance of suspended sediment transported by the main river helps to define paleoclimatic and paleoenvironmental changes in the upstream catchments. In this respect, the Nile is well suited to strontium isotopic tracer studies because 
(1) the White Nile catchment is dominated by crystalline basement rocks with high ${ }^{87} \mathrm{Sr} /{ }^{86} \mathrm{Sr}$ ratios, whereas (2) the Blue Nile-Atbara drains the Ethiopian highlands which are dominated by Cenozoic volcanic rocks with characteristically low ${ }^{87} \mathrm{Sr} /$ ${ }^{86} \mathrm{Sr}$ ratios. Both the suspended sediment and the river water in these catchments have isotopic ratios diagnostic of their source, and the ${ }^{87} \mathrm{Sr} /{ }^{86} \mathrm{Sr}$ ratio has been used successfully for provenance studies of water and sediment in the Nile system (Talbot et al., 2000; Krom et al., 2002).

Results from our study of well-dated sediment core S-21 collected in the Nile delta (Figure 1D) show a systematic decrease in the ${ }^{87} \mathrm{Sr} /{ }^{86} \mathrm{Sr}$ ratio of the $<20 \mu \mathrm{m}$ sediment fraction, from ca. 6100 B.P. to 4200 cal yr B.P. (Figure 2). At ca. 6100 cal yr B.P., a higher proportion of White Nile sediment was transported during the annual flood than towards the end of the period (4200 cal yr B.P.), when suspended sediment from the Blue Nile formed a significantly greater fraction of the total load. It has been shown that there was a simple inverse relationship between the total amount of sediment carried by the river Nile in its annual flood and the magnitude of that flood (Krom et al., 2002). This behavior was driven by the intensity and length of the rainy season on the Ethiopian Highlands. A decline in rainfall led to a decrease in the vegetative cover and an increase in the erosion rate (Foucault and Stanley, 1989).

\section{A PALEOCLIMATIC CAUSE FOR THE COLLAPSE OF THE OLD KINGDOM}

Historical records show that the Old Kingdom in Egypt continued successfully until 2160 B.C. (4160 cal yr B.P.; Kitchen, 1991) when it quite suddenly collapsed into anarchy (Bell, 1971). It has been suggested that this was due, in large part, to catastrophic failure of the annual Nile flood for a period of 30 years. This was apparently followed by a second, shorter 10-year period of drought starting in 2020 B.C. (4020 cal yr B.P.). At this time, it was written in the inscription of Ankhtifi that:

\footnotetext{
All of Upper Egypt was dying of hunger, to such a degree that everyone had come to eating his children. . . . The entire country had become like a starved (?) grasshopper, with people going to the north and to the south (in search of grain) . . . (Bell, 1971, p. 9)
}

Bell (1971) argues that the use of the Egyptian symbol $t z w$, in this and other texts, represents an image of exposed sandbanks, which, in this context, suggests that failed Nile floods caused the severe famine. There is, for example, a minimum in the ${ }^{87} \mathrm{Sr} /{ }^{86} \mathrm{Sr}$ ratio defined at a depth of $36 \mathrm{~m}$ in our delta core $\mathrm{S}-21$ record. This minimum occurs at ca. 4600 cal yr B.P. as determined from the radiocarbon measurements of Stanley and Goodfriend (1997). However, their calculation assumed that the carbonate age of the molluscs used in dating was zero initially. Core S-21 was deposited in Lake Manzalla very close to the sea. In an adjacent study, Schilman et al. (2001) have used a correction factor of 400 years for the age of planktonic foraminifera sampled from surface waters of the Levantine basin off the coast of Israel. It is, therefore, reasonable to use a similar correction for the ages of core S-21 (i.e., 400 years) to produce the age profile given in Figure 1. After such a 


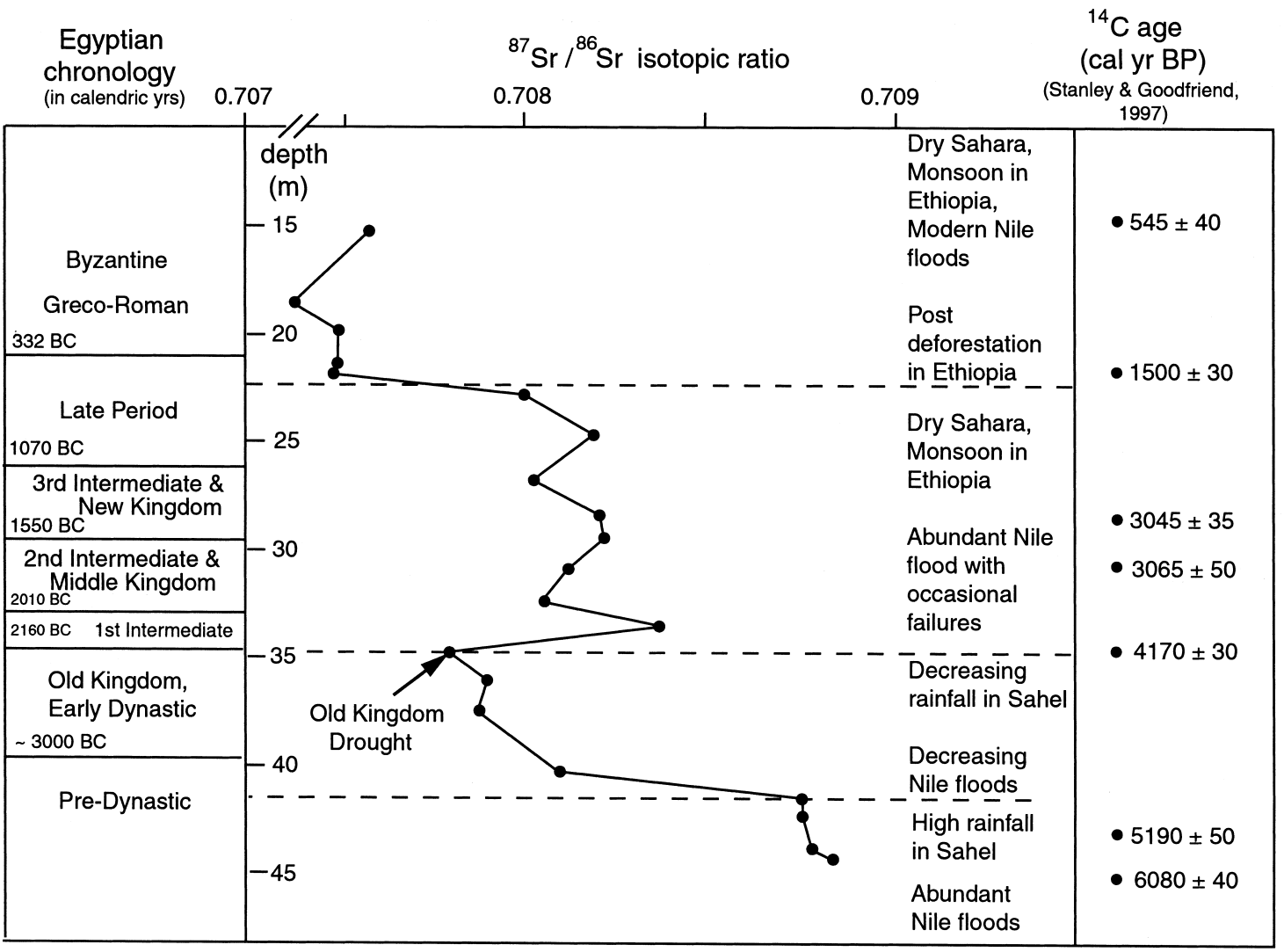

Figure 2. Depth profile of ${ }^{87} \mathrm{Sr} /{ }^{86} \mathrm{Sr}$ from core S-21 in the Nile delta (at coast, east of Suez Canal; see Figure 1D), together with interpretation of changes in paleoclimate in the catchment and the state of the Nile flood as given in Krom et al. (2002). The Egyptian chronology in calendric years, from Kitchen (1991), is given in the left-hand column. The ${ }^{14} \mathrm{C}$ calibrated age of the core, calculated by linear regression, together with the individual points from which the time-scale 

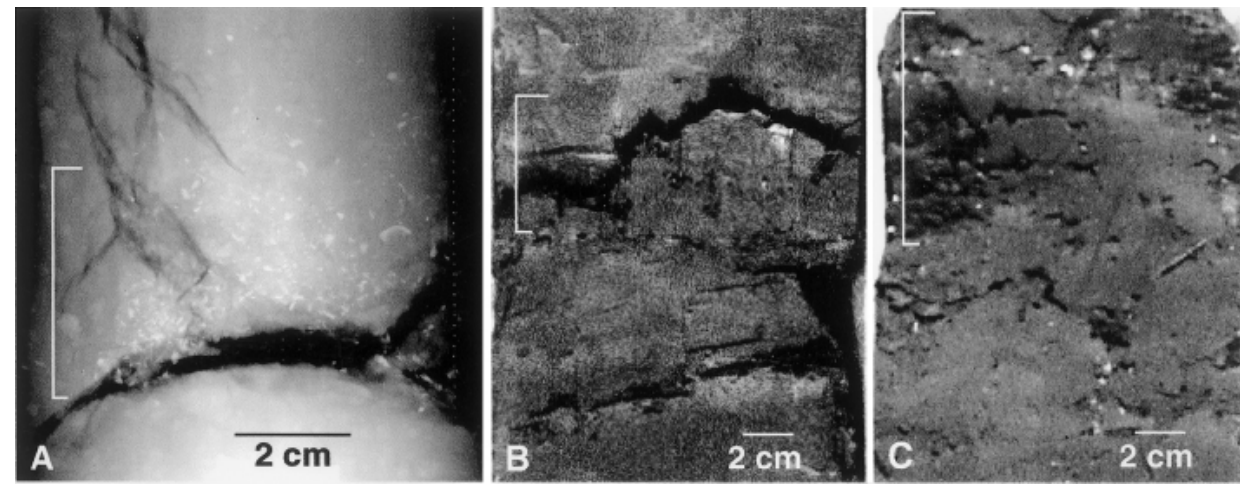

Figure 3. Core sections from two cores recovered in the Nile delta (S-86 and S-87 in Figure 1D) showing petrologic evidence of contemporaneous soil development, which resulted from subaerial drying events discussed in the text (scale in cm). Interpolated age of critical section in core S-86 (along Rosetta branch) is 4250 cal. yr B.P., and in core S-87 (near the town of Tanta) is 4050 cal. yr B.P. (A) X-radiographic image of core S-86 (core depth of ca. $5.5 \mathrm{~m}$ ) showing distinct concentrated opaque iron oxide particles [see bracketed section] in a limited depth horizon. (B) Photograph of the same depth horizon [in bracket] in core S-86 showing core level of reddish-brown silt and iron oxide concentrate formed during desiccation events. (C) Photograph of brown silt horizon [in bracket] in core S-87 (depth ca. $4.75 \mathrm{~m}$ ) of similar age to that of core S-86 (A, B).

correction is made, the age of the minimum in the ${ }^{87} \mathrm{Sr} /{ }^{86} \mathrm{Sr}$ ratio defined at a depth of $36 \mathrm{~m}$ becomes ca. 4200 cal yr B.P.

In the prophesy of Neferty, which remembers the short and chaotic 1st Intermediate Period, it is written that:

"The river of Egypt is empty, men cross over the water on foot" and that "Birds no longer hatch their eggs in the swamps of the delta . . . " (Bell, 1971, p. 17).

At present, the flow of the White Nile is maintained by equatorial rainfall and is reasonably constant throughout the year, supplying most of the baseflow during nonflood periods (Said, 1993). The above writings imply that the baseflow component from the White Nile was also exceptionally low during this drought period, indicating that this climatic anomaly affected the entire catchment. Direct evidence for such low baseflow at that time is provided by two cores collected in the central Nile delta (cores S-86, along the Rosetta branch, and S-87, near the town of Tanta), which were recovered within the freshwater region (Figure 1D). A distinctive thin $(\sim 5 \mathrm{~cm})$, reddish-brown silt layer containing iron/manganese hydroxide is present in each core and nowhere else within the two mid-Holocene core sections (Stanley et al., 1996). Sediment that has been allowed to dry out in air will form iron oxides that are resistant to later chemical changes, even once the delta system becomes flooded again. Visually, these layers resemble modified paleosol horizons (Figure 3) characteristic of sediment that has dried out and been subaerially exposed for a prolonged period. Note that the ages of these two horizons are $4250 \mathrm{cal}$ yr B.P. 
in core S-86 and 4050 cal yr B.P. in core S-87, based on interpolated radiocarbon ages from these cores (cf. Stanley et al., 1996). It is also useful to recall the similar age, ca. 4200 cal yr B.P., of the sediment section defined by the minimal isotopic ratio in Nile delta coastal core S-21.

These observations are consistent with previous studies of the White Nile catchment that suggest that water flow from this major but more distal branch of the river was also reduced at this time. For example, the outflow from Lake Turkana, which used to feed water into the White Nile basin, ceased at ca. 4400 cal. yr B.P. (Owens et al., 1982). It has also recently been established that the Lake Victoria outflow ceased for a short period at about this time (M. Talbot, 2002, personal communication). Moreover, the Yellow Nile, which flowed down Wadi Howar (Figure 1A) into the main Nile at Old Dongola, in northern Sudan, finally ceased to flow at about 4500 yr B.P. (Pachur and Kröpelin, 1987).

\section{WIDER IMPLICATIONS OF THIS STUDY}

Drought was widespread at ca. 4200 cal yr B.P. across Egypt and much of Africa and Asia, and this abrupt climatic event has been implicated in the collapse of civilizations in Syria, Mesopotamia, Turkey, and elsewhere (Dalfes et al., 1997; Weiss, 2000). This widespread event may have been caused by weak monsoons induced by a change in the circulation of the North Atlantic (Street-Perrott and Perrott, 1990; Gasse, 2000). The systematic changes in both the annual flood and baseflow of the river Nile, which we document here with new geoscience data, are simultaneous with the end of the Old Kingdom in Egypt within our time resolution. However, given the inherent problems of radiocarbon dating (Stanley, 2001), it remains difficult to unambiguously identify events as short as several decades from conventional radiocarbon determinations alone. It thus becomes necessary to combine detailed archaeological information and chronologies with geochemical and petrological data, as presented here, to resolve and more accurately interpret shortterm paleoclimatic events such as the one leading to the collapse of the Old Kingdom.

Funding for petrologic analysis of the cores (DJS) was provided by the Walcott Fund of the National Museum of Natural History, Smithsonian Institution. This manuscript was written during the sabbatical leave of MDK which was funded by the Leverhulme Trust (RFG/10307).

\section{REFERENCES}

Adamson, D.A., Gasse, F., Street, F.A., \& Williams, M.A.J. (1980). Late Quaternary history of the Nile. Nature, 288, 50-55.

Bell, B. (1971). The Dark Ages in ancient history: The first dark age in Egypt. American Journal of Archaeology, 75, 1-25.

Butzer, K.W. (1976). Early hydraulic civilisation in Egypt. Chicago, IL: Chicago University Press.

Dalfes, H.N., Kukla, G., \& Weiss, H. (1997). Third Millennium BC climate change and Old World collapse, NATO Scientific Affairs Division. New York: Springer-Verlag.

Foucault, A., \& Stanley, D.J. (1989). Late Quaternary palaeoclimatic oscillations in East Africa recorded by heavy minerals in the Nile delta. Nature, 339, 44-46. 
Gasse, F. (2000). Hydrological changes in the African tropics since the Last Glacial Maximum. Quaternary Science Reviews, 19, 189-211.

Gasse, F., \& van Campo, E. (1994). Abrupt post-glacial climate events in West Asia and North Africa monsoon domains. Earth and Planetary Science Letters, 126, 435-456.

Gillespie, R., Street-Perrott, F.A., \& Switsur, R. (1983). Post-glacial arid episodes in Ethiopia have implications for climate prediction. Nature, 306, 681-682.

Hassan, F.A. (1986). Holocene lakes and prehistoric settlements of the Western Faiyum, Egypt. Journal of Archaeological Science, 13, 483-501.

Hassan, F.A. (1997). Nile floods and political disorder in early Egypt. In N. Dalfes, G. Kukla, \& H. Weiss (Eds.), Third Millennium BC climate change and Old World collapse, NATO ASI Series 1 (Volume 49, pp. 1-24). New York: Springer.

Kitchen, K.A. (1991). The chronology of ancient Egypt. World Archaeology, 23, 201-208.

Krom, M.D., Stanley, D., Cliff, R.A., \& Woodward, J.C. (2002). Nile River sediment fluctuations over the past $7000 \mathrm{yr}$ and their key role in sapropel development. Geology, 30, 71-74.

Lario, J., Sanchez-Moral, S., Fernandez, V., Jimeno, A., \& Menendez, M. (1997). Palaeoenvironmental evolution of the Blue Nile (Central Sudan) during the early and Mid-Holocene (Mesolithic-Neolithic transition). Quaternary Science Reviews, 16, 583-588.

Leng, M.J., Lamb, A.L., Lamb, H.F., \& Telford, R.J. (1999). Palaeoclimatic implications of isotopic data from modern and early Holocene shells of freshwater snail Melanoides tuberculata, from lakes in the Ethiopian rift valley. Journal of Palaeolimnology, 21, 97-106.

Owens, R.B., Barthelme, J.W., Renaut, R.W., \& Vincens, A. (1982). Palaeolimnology and archaeology of Holocene deposits northeast of Lake Turkana, Kenya. Nature, 298, 523-529.

Pachur, H.J., \& Kröpelin, St. (1987). Wadi Howar: Paleoclimatic evidence from an extinct river system in the southeastern Sahara. Science, 237, 298-300.

Ritchie, J.C., Eyles, C.H., \& Haynes, C.V. (1985). Sediment and pollen evidence for an early to midHolocene humid period in the eastern Sahara. Nature, 314, 352-355.

Said, R. (1993). The River Nile. Oxford: Pergamon Press.

Schilman, B., Almogi-Lapin, A., Bar-Matthews, M., Labeyrie, L., Paterne, M., \& Luz, B. (2001). Long- and short-term carbon fluctuations in the Eastern Mediterranean during the late Holocene. Geology, 29, 1099-1102.

Stanley, D.J., \& Goodfriend, G.A. (1997). Recent subsidence of the northern Suez Canal, Nature, 388, $335-336$.

Stanley, D.J., McRae, J.E., Jr., \& Waldron, J.C. (1996). Nile delta drill core and sample database for 19851994: Mediterranean Basin (Mediba) Program, Smithsonian Contribution to the Marine Sciences. Washington, DC: Smithsonian Institution.

Stanley, J.D. (2001). Dating modern deltas: progress, problems and prognostics. Annual Review of Earth and Planetary Science, 29, 257-294.

Street-Perrott, F.A., \& Perrott, R.A. (1990). Abrupt climate fluctuations in the tropics: The influence of Atlantic ocean circulation. Nature, 343, 607-611.

Talbot, M.R., Williams, M.A.J., \& Adamson, D.A. (2000). Strontium isotope evidence for late Pleistocene re-establishment of an integrated Nile drainage network. Geology, 28, 343-346.

Weiss, H. (2000). Beyond the Younger Dryas, In G. Bawden \& R. Reycraft (Eds.), Confronting natural disaster: Engaging the past to understand the future (pp. 75-98). Albuquerque, NM: University of New Mexico Press.

Welsby, D.A. (2001). Life of the desert edge: Seven thousand years of settlement in the Northern Dongola Reach, Sudan, Sudan Publication No. 7. London: Archaeological Research Society.

Woodward, J.C., Macklin, M.G., \& Welsby, D.A. (2001). The Holocene fluvial sedimentary record and alluvial geoarchaeology in the Nile Valley of northern Sudan. In D. Maddy, M.G. Macklin, \& J.C. Woodward (Eds.), River basin sediment systems: Archives of Environmental Change (pp. 327-355). Rotterdam: A.A. Balkema.

Received July 1, 2002

Accepted for publication September 2\%, 2002 